Review Essay

\title{
DOVES DEVOURED, THE SERPENT REMAINS: ON THE NEED FOR A SCIENTIFIC CRITIQUE OF ETHICS
}

\author{
PAUL CHRISTOPHER GRAY \\ York University
}

\begin{abstract}
Blackledge, Paul. 2012. Marxism and Ethics: Freedom, Desire, and Revolution. Albany: State University of New York Press. ISBN 978-14384-3991-4. Hardcover. 80.00 CAD. Pages: 249.

Noonan, Jeff. 2012. Materialist Ethics and Life-Value. Montreal \& Kingston: McGill-Queen's University Press. ISBN 978-0-7735-3965-5. Paperback. 34.95 CAD. Pages: 256.
\end{abstract}

\footnotetext{
"All sciences are born "inexact." Sebastiano Timpanaro $(1976,216)$
}

When it comes to morality, "the silence of Marx, and most Marxisms, is so loud as to be deafening." So said E. P. Thompson (1978, 363). Although he overstated his case, since that time there has emerged a "Marxism and Morality" industry that has nevertheless been met with - outside of certain academic circles - near total silence. While this is due in part to the marginalization of workers' power and socialist critique in recent decades, it is also due to the inadequate character of these interventions. Indeed, the scientific critique of ethics remains in its embryonic form.

In light of this, two new texts offer welcome contributions to the debate. Jeff Noonan's Materialist Ethics and Life-Value is an ambitious post-Marxist attempt to create a socialist ethics based on what he calls the "life-ground of value." Paul Blackledge's Marxism and Ethics traces the entire history of Marxist interventions in ethical debates in an attempt to counter the former Marxist Alasdair MacIntyre's assertion that Marxism does not pose a plausible alternative to liberalism because, in the realm of moral theory, Marxists have always resorted to either Benthamite consequentialism or Kantian formalism, and in the realm of practice, Weberian bureaucratism. Blackledge begins his first chapter by quoting one of Hegel's declarations of method: 
The refutation must not come from outside, that is, it must not proceed from assumptions lying outside the system in question and inconsistent with it. The system need only refuse to recognise those assumptions; the defect is a defect only for him who starts from the requirements and demands based on those assumptions (Blackledge 2012, 19).

This "immanent critique" uses historical context to invade the inner logic of an opponent's theory and demonstrates how, according to its own standards, its selfdescribed universal truth-claims are only a partial, one-sided, and self-contradictory reflection of conflicts inherent to the prevailing social conditions. By identifying suppressed contradictions, immanent critique determines latent social potentials that, if they are realized by a social force uniquely capable of doing so, achieve the universality that the refuted ideology falsely claims to already exist. This interchange between theory and practice is crucial because, unless we distil the particular tendencies and laws of the prevailing social conditions, any attempt to transform them will become dominated by them.

Although Noonan and Blackledge make valuable contributions, they prove inadequate according to these standards of immanent criticism: Noonan poses, in Feuerbachian fashion, a "materialist" ethics that, because it proceeds from assumptions lying outside of capitalist society, is actually a species of idealist utopianism; Blackledge employs overview, commentary, and in the case of Marx, exegesis, but never immanent critique, because he misinterprets what a refutation of MacIntyre necessarily entails. Before these claims can be substantiated, however, we must first explore the significance of these ethical debates for workers' power and socialist strategy.

There are a number of reasons why engagement with ethics has never been more important for socialist thought and practice. First, socialists must account for the disastrous attempts to create socialism in the twentieth century, and delineating their failures as not only economic and political but also as ethical projects is a crucial dimension of this atonement.

Second, a crucial facet in the redemption of historical materialism is its application to ethics, a form of human activity that is deemed by all variants of positivism as the least susceptible to scientific treatment, an endeavour by which historical materialism can demonstrate its continuing cogency as the science of capitalist society.

Third, as capitalism develops it necessitates socialist practice that is decreasingly insurrectionary and increasingly prefigurative of the post-capitalist society. In the revolutions of 1648 and 1789, the popular classes in London and Paris were politicized by splits in the ruling class; in 1848, revolutionary proletarian clubs inspired pan-European revolts; in 1871, the National Guard elected the Communal Council to fill the political vacuum in war-weary Paris; in 1917, 1949, and elsewhere, well-established parties came to power through the insurrectionary "war of manoeuvre." It was Gramsci's great insight 
that in the most advanced capitalist conditions the "cultural revolution" must occur in the "trenches and earthworks" of civil society before, during, and after "smashing the state" (Gramsci 2000, 225-30). This prefigurative "war of position" is surely the launching point for all innovations in the project for twenty-first century socialism. Indeed, the critique of ethics is necessary for, on the one hand, moving beyond the vestiges of insurrectionary politics that pervade even the best representatives of the Leninist, Trotskyist, and postTrotskyist traditions, and on the other hand, for seizing ground from the recently ascendant anarchists who claim to be the only genuinely prefigurative form of radicalism.

Fourth, in comparison to its entire history, ethical activity is in a state of unprecedented degradation under the "impersonal dependence" of capitalist social relations. While its relation to political activity has always been one of opposition as much as of interpenetration, the circumscription of ethics in its relation to the capitalist economy is historically unique. In all precapitalist class societies, rulers and producers were tied together by traditional, paternalistic codes of obligation that normatively regulated material production. Conversely, in capitalism, the totalizing spread of the market and its commodity logic abstracts from the personal characteristics of both producers and rulers, reducing them to mere personifications of wage-labour and capital. This has caused the dissolution of customs incompatible with the maximization of exchange-value, the differentiation of human activities into discrete social spheres that do not admit of any but the most abstract common societal ends, and widespread depictions of the capitalist market as a "non-moral" realm. Far from affirming the irrelevance of ethics for socialist practice, the precise delineation of this circumscription is necessary before we can determine how ethics can become adequate to those forms of human activity that are currently deemed autonomously "economic" and "political."

Finally, there is a serious lacuna in all socialist theory. Lenin, for example, asserts that -economic preconditions aside - the state will be able to wither away completely "when people have become so accustomed to observing the fundamental rules of social intercourse" that "they will voluntarily work according to their ability" (1970, 357). Lenin's theory, like all socialist theory, envisions the displacement of the state by processes of self-regulation. Nevertheless, that the state and therewith politics can "wither away" provokes skepticism because of the many cases where the "dictatorship of the proletariat" became a dictatorship over the proletariat. Speaking on the relation between politics and ethics, Kant once prescribed: "Be ye therefore wise as serpents, and harmless as doves." In its current form, the socialist account of a politics that eliminates all politics gives the impression of a snake eating its own tail: no matter how much it devours, the serpent remains. A coherent ethics is necessary if the victorious proletariat is to shed its political skin. With this in mind, we must now turn to Noonan and Blackledge.

The foundation of Noonan's materialist ethics is the "life-ground of value", which is the "bond of being" between life and "life-requirements" (Noonan 2012, 23). The lifeground for humans derives from three dimensions of human nature. All humans are 
organisms with physical-organic life-requirements for things like food and water; are potentially self-conscious agents with socio-cultural life-requirements for things like familial love and education; and, are finite beings with temporal life-requirements for the free time necessary for the realization of creative human capacities (52). This provides the baseline of "materially rational judgments". Regardless of whether or not the individual desires it, what is materially rational and therefore good is that which satisfies liferequirements in ways that contribute back to the fields of natural and social life-support; what is materially irrational and therefore not good is that which is deleterious and selfundermining to life-activity (43). By distinguishing between what does and does not sustain life, materially rational evaluations are "objective judgments" about satiable and non-voluntary life-requirements, not "subjective preferences" for mere wants that are insatiable and subject to wilful change (11).

The life-grounded materialist ethics aspires to "a society whose systemrequirements prioritize the satisfaction of the shared life-interest of each and all" (106). When the ruling money-value system treats basic life-requirements as instruments of its own growth and objective harm is systematically imposed on certain groups of people because they lack an arbitrary system-requirement like money, "life-grounded materialist ethics concludes not only that the ruling value system is ethically wrong but that it requires systematic transformation" (13).

Noonan articulates his concept of "life-requirement" in opposition to Marx's concept of "need." According to Noonan, Marx uncritically adopts Adam Smith's conception of "use-value" and therefore "conflates human needs with consumer demands, thereby opening the door to ecologically unsustainable conceptions of socialism as unlocking the secret to limitless wealth" (7). According to Noonan, Marxists tend to valorize the development of productive forces as intrinsically good, but if usevalues are not grounded in the concept of "life-value," "there is no internal brake on the possibility that socialism too becomes driven to materially irrational scales of production" (141). Therefore, Noonan posits a non-Marxist socialism whose basis is not the class interests of the proletariat but the internal and external nature shared by all humankind (97). There is much to find at fault with this account.

Noonan misinterprets Marx's conception of “need” because he attributes qualities to use-value that are only true of exchange-value. For Marx, wage-labour and capital are necessarily opposed because the needs of workers set limits to the valorization of capital and the needs of capitalists set limits to the reduction of labour-time (Heller 1976, 26). Furthermore, whereas the limited nature of needs is an obstacle to the valorization of capital, quantitative measures admit of no principle of self-limitation, and thus measuring need in terms of an abstract standard such as money ensures that enough cannot exist (Gorz 1989, 111-114). Marx envisions a society dedicated solely to the production of usevalues because humankind pursues its needs in a human way only when its needs are limited by nothing but other needs (Heller 1976, 43). This means, on the one hand, that 
need is not externally limited by the valorization of capital, and on the other, that without a mediating abstract general equivalent like money, needs are pursued in direct, qualitative, incommensurable, and therefore self-limiting ways. Thus, only use-values dominated by exchange-values are "unlimited". Consequently, Noonan does not provide a compelling reason to abandon Marx's concept of "need."

Even if capitalism is "materially irrational" and therefore "unethical" according to the standards of the life-grounded ethics, adherents to the prevailing social conditions can condemn these standards as utopian. This is why Marx critiques political economy from the perspective of capital, demonstrating the contradictions that emerge on its own terms. Marx begins Capital with the commodity and the distinction between use-value and exchange-value because everyone under capitalism, including capitalists, experiences capitalism as a world of commodities. He does not begin with and never resorts to an external standard. Marx not only demonstrates the ways in which the dominance of exchange-value gives rise to contradictions such as commodity fetishism, hidden surplus appropriation, and the mechanical degradation of the worker. More importantly, at the projected end of the unfinished volumes of Capital when we return to the commodity as the world trade of commodities, the basic contradiction between use-value and exchangevalue persists. Only then can Marx prove scientifically that, even from the perspective of capital, the revolutionary proletariat is the sole social force capable of transcending exchange-value which, of course, entails socialism. Critiques such as these prove theoretically what the proletariat must prove in the practice of hegemony, namely, that they are the universal class because their particular interests can be the universal interest.

Marx could only come to these conclusions because his conception of "need" is not need in general but need as expressed through specific social relations. Conversely, Noonan's ethics, like all forms of Natural Law, contends that an unchanging human nature is the basis of a practical rationality that is universally binding. Noonan is a modern-day Feuerbach who reduces the human essence to "an internal, dumb generality which merely naturally unites the many individuals" (Marx 1978, 145). Noonan imposes an abstractly universal conception of human nature rather than determining the latent ethical potentials dwelling within the historically specific laws of capitalism and its developing balance of social forces, the full realization of which not only demands the overthrow of capitalism but also develops the capacities necessary to replace it with something viable. Furthermore, Noonan's ahistorical appeal to the immediate intelligibility of life-requirements (51) neglects the extent to which the division of labour and class stratification mediate social relations, imbuing historically specific forms of human activity with the appearance of immutable laws of nature.

One of the most trenchant analyses of this form of fetishism is Alasdair MacIntyre's After Virtue. MacIntyre contends that the dominant form of modern morality is not deontology or utilitarianism but "emotivism," the theory that moral 
judgments are not factual claims capable of truth or falsity because moral agreement derives not from rational criteria but from non-rational expressions of personal preference $(1984,12)$. No matter what their avowed theoretical standpoint, "to a large degree people now think, talk and act as if emotivism were true" (22). MacIntyre asserts that this is a uniquely modern sentiment, and yet, by asserting that all moral utterance is a mask for mere personal preference, emotivists take this to be true for every society in human history (23). This abandonment of any substantive universality in ethics has dire consequences. Where there is no longer a shared conception of the human good, there is no coherent concept of what it is to contribute more or less to that good (232). Consequently, there is a dearth of "moral resources" capable of rationally settling moral disagreements (252). This has left local communities helpless in the face of their destruction by the market and the state. Against this trend, MacIntyre attempts to salvage precapitalist forms of virtue ethics, specifically those of Aristotle and Aquinas, to which he attaches his infamous apocalyptic vision: "What matters at this stage is the construction of local forms of community within which civility and the intellectual and moral life can be sustained through the new dark ages which are already upon us" (263). It is to these sentiments that Blackledge responds, and thus it is to him we must now turn.

Spurning the deontological emphasis of duty and the utilitarian concern for consequence, modern virtue ethics returns to Aristotle's Nicomachean Ethics, accentuating the character traits, practical wisdom, and forms of community necessary for an objective "human flourishing" that is more substantial than mere subjective contentment. This "aretaic turn" inspired a group of what could be called the "Nicomarxian ethicists," of which Blackledge is a most active member. When his Marxism and Ethics makes the aforementioned clarion call to immanent critique, Blackledge has in mind

Alasdair MacIntyre's claim that no modern moral theory is able to provide a rationally justifiable guide to action, but rather that each approach is best understood as a more or less coherent justification of personal preferences... MacIntyre also claims that Marx's suggested alternative to this emotivist culture must ultimately be judged a failure. The rest of the book is best read as an extended discussion of and attempted answer to this criticism (15).

Blackledge attempts to demonstrate that Marxism provides the theoretical resources to extricate ourselves from the crisis of modern moral philosophy by showing how collective working class struggle embodies a virtuous alternative to utilitarianism, deontology, and emotivism.

Blackledge's text is pervaded by a sentiment of "going back to Marx": 
Against the dominant reading of these texts, according to which 'no interpretation of Marx's various remarks on justice and rights can make them all consistent with one another,' I follow those, such as Albert Gilbert and Roy Edgley, who have suggested that a coherent ethics can be reconstructed from [Marx and Engels'] writings once they are adequately contextualized and understood (45).

Poulantzas once argued that the political theories offered by Marx, Engels, Lenin and Gramsci provide important conjunctural analyses, but it remains the task of contemporary Marxists to conduct a strictly political science in the manner of Marx's scientific critique of political economy $(1975,20-23)$. This is even truer of ethics. Although a theory of ethics is not incompatible with Marxism and what little Marx and Engels say about ethics is not inconsistent, this cannot provide the materials by which to "reconstruct" a coherent ethics because they themselves did not construct a coherent ethics.

This is one of the reasons why the Nicomarxian ethicists put such emphasis on Aristotle. To refute MacIntyre's claim that Marxism does not pose an ethical alternative to liberal morality, Blackledge attempts to prove that Marx is an implicit Aristotelian. Shall we also go back to Aristotle?

Blackledge asserts that Marx sublates idealism and materialism with a Hegelian reading of Aristotle's essentialism (20). This is dubious: there is nothing in Aristotle's conception of "essence" that is not improved upon by Hegel. It is really the concept of "virtue" that brings Blackledge back to Aristotle because he interprets immanent critique to mean that proving Marx's Aristotelianism fills the gaps attributed to Marx by MacIntyre according to MacIntyre's own Aristotelian standards. But a true immanent critique would demonstrate that MacIntyre's virtue ethics is inadequate according to its own standards and that Marxism alone can resolve its contradictions. Marxism, such as it exists now, cannot accomplish this because it requires a historical materialist critique of ethics, a task that, to my knowledge, has never been undertaken successfully.

This is why Blackledge reads the concept of "virtue" into Marx's work:

Marx suggested not only that workers feel compelled to struggle against the power of capital, but that in so doing they begin to create modes of existence which also offer a virtuous alternative to the egoism characteristic not only of capitalist society generally, but also of workingclass life within that society more specifically (93).

But Marx does not use the concept "virtue" in any substantive way here or anywhere else. Instead, Marx uses the concept "need" and in particular "new needs." As if to prove this point, immediately after this statement, Blackledge quotes Marx: "When communist 
workmen gather together, their immediate aim is instruction, propaganda, etc. But at the same time, they acquire a new need-the need for society-and what appears as a means had become an end" (93). Here too Marx derives his inspiration not from Aristotle but Hegel, as is evident from, say, MacIntyre's account of Hegel's ethical philosophy:

What passions and what ends the individual has and can have are a matter of the kind of social structure in which the individual finds himself. Desires are elicited and specified by the objects presented to them; the objects of desire, and especially of desires to live in one way rather than another, cannot be the same in all societies. But it is not necessarily the case that the desires elicited by a particular form of social life will find satisfaction within that form. The working out of the ends of contemporary practice may, in fact, destroy the very form of life which brought the desire for those ends into being (1966, 200-201).

Marx makes his "wager" on the working class because he deems it to be the only social force that has certain "imperative" needs, the full satisfaction of which demands the transcendence of capitalism (Marx and Engels 1956, 52-3).

A crucial aspect of the hegemonic class-formation of capital was the articulation of an independent ethics, as was the case, for example, with the Puritan movement and the English bourgeoisie (Tawney 1975). This is why MacIntyre's apt critique of Marxism is so devastating. That the Revisionists and Ethical Socialists adopted a form of Kantian deontology, or that their antagonist, Kautsky, adopted a form of consequentialism, embedded bourgeois antinomies into the workers' movement and hampered the development of an independent ethics and thus a rival hegemonic class-formation of the working class. It is therefore peculiar that the Nicomarxian ethicists, in their attempt to refute MacIntyre, only confirm his critique by aping his ethical philosophy. Although "virtue" must surely be a crucial aspect of a scientific ethics, it is not the foundational concept. In the same way that the "labour theory of value" and the "class theory of the state" provide the materialist foundations for the sciences of political economy and politics, "need" is the materialist foundation for a scientific ethics. Nevertheless, although "need" is a crucial concept for Marx, it is not sufficiently elaborated. That task falls to us. Only a few cursory propositions can be articulated here.

Ethics is a form of praxis. Raising an image of ourselves and realizing it through our practical activity is how we produce ourselves as ethical beings. Reconciling our needs with the needs of others entails the capacity to displace certain immediate needs for the sake of higher needs possible only through cooperation. Like other forms of praxis, ethical activity can become reified, fetishized, and alienated. This, however, does not necessitate some form of pre-capitalist communitarianism. Devoid of a social force capable of carrying out his virtue ethics, MacIntyre draws only pessimistic conclusions 
about modern morality. Nevertheless, while the widespread emotivist belief that ethics is nothing but the expression of personal preferences is certainly debilitating for collective action, the devastation of traditional customs and the proliferation of incommensurable moral standards already presents in germ-form what only the collective action of a universal class can bring out in full relief, namely, that humans engaged in historically specific social relations are the source of all ethical values and therefore these values must be adapted to our current needs.

This is why a scientific ethics must stake its independence from all moral theories that disassociate morality from need by, for example, describing happiness as a "nonmoral" good. By disassociating morality from need, these theories can proclaim the adequacy of a universal morality in a class-divided society. Conversely, a materialist ethics that roots ethics in human need must demonstrate the contradictory character of needs in capitalism, expose the abstract character of moralism disassociated from need, and prove that the specific conditions within which needs can be reconciled by a truly universal ethics is the classless society.

MacIntyre asserts that, due to its distinction between the so-called economic "base" and the ideological "superstructure," Marxism reproduces the academic dualism that separates theory and practice $(1984,61)$. This common refrain neglects, among other things, how Marx argues that the extension of the working day encounters not only physical but also moral obstacles, specifically the need for time to satisfy intellectual and social requirements as conditioned by the general level of civilization: "In contrast, therefore, with the case of other commodities, the determination of the value of labourpower contains a historical and moral element" (1977, 341; 275). Far from a mere superstructural epiphenomenon, Marx embeds morality in the supposedly "non-moral" economic "base." This has crucial implications for working class hegemony.

When workers have as their main demand the increase of wages, they are but one particular class, wage-labour, against another particular class, capital, and therefore act entirely within the parameters of capitalism. But when workers have as their main demand the need for more free time, they affirm the needs of the human species as a whole (Heller 1976, 91). Sacrificing their immediate needs, class conscious workers orient the particular interests of a strata or class to the universal interests of all humanity and thereby demonstrate their potential as the truly universal class.

All moralism is a species of idealism. We must avoid a "moral economy" approach (Thompson 1993) that unduly imposes moralistic criticisms of "economic agents" in an impersonal market that, abstracting from the personal characteristics of its participants, circumscribes, in specific and variegated ways, the personal freedom necessary for moral responsibility. Nevertheless, collective action by workers militates against competitive imperatives, demonstrating that the extent to which the market is a "non-moral" realm is, even within capitalism, historically determined. In other words, the expansion of collective action increases the scope of personal responsibility. This exposes and 
undermines the alienation of formerly ethical activities into a purely "economic" practice that is relatively autonomous from normative regulation, and thereby creates, if only in germ-form, the new need for the subordination of production and distribution to the ethical self-regulation of free associations, the full realization of which entails socialism. This takes us directly to the question of politics.

Noonan and Blackledge seem to share a belief in the unity of ethics and politics. Noonan asserts that this unity follows from the natural dependence and social interdependence between individuals and the world (192). Blackledge contends that both Aristotle and Marx affirm the unity of ethics and politics: "just as Aristotle posited a natural movement from ethics to politics - 'The science that studies the supreme Good for man is politics' - Marx moved from formulating a model of human good to fighting for the political implications of this model" (3). Thus, Marx's politics is not in crude opposition to morality, but a practice that overcomes the opposition between materialism and idealism (198).

Insofar as Blackledge is demonstrating the ethical dimension of workers' power in order to rebut claims that Marx affirmed an insurrectionary Blanquism, he is correct. Nevertheless, a scientific ethics must delimit the ways in which, even in the practice of workers' power, ethics is necessarily opposed to politics. Even if Aristotle posits a "natural movement" from ethics to politics, Marxists cannot posit anything but a historical movement.

The transitions from the precapitalist to the capitalist market order - wherein the appropriation of surplus labour is separated from the public political functions of the state - have been described as the differentiation of the economic from the political (Wood 1995, 31). This is only a partial explanation. If anything, the impersonal dependence of capitalism inaugurates the differentiation of the economic from the personal-normative, which contains within it the contradiction between ethics and politics. Long before these events, the transitions from hunter-gatherer societies to state societies gave rise to what can be described as the differentiation of the political from the ethical. In hunter-gatherer societies, complex networks of customary reciprocity regulated the collection and distribution of resources without a state and its legal edifice. For a substantial portion of human history, this suited the limited development of material production. If ethics is the active reconciliation of needs within and between individuals, then the developing division of labour, the gradual differentiation of society into classes, and the emergence of antagonistic needs undermined the capacity of ethics to maintain order: ethics became inadequate to its changing social conditions. Indeed, the emergence of the state "is the admission that this society has involved itself in insoluble self-contradiction and is cleft into irreconcilable antagonisms which it is powerless to exorcise" (Engels 1975, 229). Politics is no more capable than ethics of reconciling these necessarily antagonistic needs, but unlike the decentralized self-regulation typical of local 
custom, political activity, with its territorial concentration of systematic coercion in the hands of a ruling class, can hold this clash of needs in abeyance. Politics does not eliminate but rather displaces ethics, subordinating it to the state regulation of the social order: "Law and custom both involve the regulation of behaviour but their characters are entirely distinct" (Diamond 2007, 260).

Ethical theory, so often isolated from political concerns, is therefore merely subpolitical, incapable of solving the tasks it sets itself, for these dilemmas emerge from structural antagonisms that demand social transformations and thereby an ethical activity that undergoes processes of politicization. The precise relation between ethical and political activities is always a matter of history, but this relation often appears "natural" because its historical differentiation is not immediately intelligible. In politics, ethics must learn to see itself in alienated form.

Far from undermining the Marxist theory of revolution, this opposition is one of its main justifications. In the same way that a scientific ethics must demonstrate how the domination of exchange-value over use-value and the concomitant antagonism between economic and ethical activities give rise to contradictions that are irresolvable from the perspective of capital, it must also demonstrate that the dominance of politics over ethics is similarly irresolvable.

Even the revolutionary proletariat, in the lead up to and taking of state power, cannot resolve the contradiction between ethics and politics because it must use the coercive apparatus of the state to suppress the bourgeoisie and its allies. Nevertheless, the "war of position," wherein the revolutionary proletariat orients its needs to those of the manifold subaltern strata and raises otherwise partial struggles to a more universal collective will (Gramsci 1970, 137), must prefigure the future self-regulating society by developing the relationships, organizations, and capacities, the new needs and "moral resources," necessary to displace the state. This is the terrain upon which the critique of ethics must obtain its raw data. Lest the revolutionary proletariat turn this coercive apparatus against itself, ethical activity must be made adequate again. Only then can public institutions administer things rather than administering people as if they are things. Ethics is to Marxists what poverty is to Christians: it will always be with us. This is the optimism of politics, which can wither away, and the pessimism of ethics, which is as eternal a human condition as is our metabolism with nature.

An ethics made adequate again would entail processes of self-regulation that subsume the redeemable aspects of those activities presently called "economic" and "political," such as the production for use-value or public administration, while eliminating those aspects that are incompatible with the reconciliation of ethical, economic, and political activities, such as the dominance of exchange-value or the concentration of the means of coercion in the hands of a ruling class. Actively bridging otherwise separate and often contradictory social spheres by unleashing the latent universal potential in each is how a more universal collective will, embodied by the 
revolutionary strata of the working class, can seize ground from the prevailing "emotivist" culture in the struggle for hegemony.

Engagement with ethics has never been more important for socialist thought and practice, and yet the science of ethics remains in its infancy. Shall we go back to Marx? Yes, but the resources Marx provides are not in his few cursory remarks about ethics but in his method, which must now be applied and adapted to ethical activity. We must descend from all royal roads so that we might navigate the trenches and earthworks. If we began with Hegel's declaration of immanent critique, perhaps it is appropriate to end with one of his most trenchant questions: With what must a science begin? Hegel begins his mature science with Being; Marx with the commodity. With regard to ethics, mired in its embryonic stage, we can only reply, science must begin with the aspiration for scientific enquiry itself.

\section{References}

Diamond, Stanley. 2007. In Search of the Primitive. New Brunswick: Transaction Publishers.

Engels, Frederick. 1975. The Origin of the Family, Private Property and the State. New York: International Publishers.

Gorz, André. 1989. Critique of Economic Reason. London: Verso.

Gramsci, Antonio. 1970. “The Modern Prince." In The Modern Prince and Other Writings. New York: International Publishers.

Gramsci, Antonio. 2000. The Antonio Gramsci Reader. ed. David Forgacs. New York: New York University Press.

Heller, Agnes. 1976. The Theory of Need in Marx. New York: St. Martin's Press.

Lenin, V. I. 1970. “The State and Revolution.” In Selected Works: Volume Two. Moscow: Progress Publishers.

MacIntyre, Alasdair. 1966. A Short History of Ethics. New York: Macmillan Publishing Company.

MacIntyre, Alasdair. 1984. After Virtue. Indiana: University of Notre Dame Press. 
Marx, Karl. 1977. Capital Volume One. New York: Random House.

Marx, Karl. 1978. “Theses on Feuerbach.” In The Marx-Engels Reader. ed. Robert C. Tucker. New York: W. W. Norton \& Company, Inc.

Marx, Karl and Frederick Engels. 1956. The Holy Family. Moscow: Foreign Languages Publishing House.

Poulantzas, Nicos. 1975. Political Power and Social Classes. trans. Timothy O’Hagan. London: New Left Books.

Tawney, R. H. 1975. Religion and the Rise of Capitalism. Middlesex: Penguin Books Ltd.

Thompson, E. P. 1978. "The Poverty of Theory." In The Poverty of Theory and Other Essays. London: Merlin Press.

Thompson, E. P. 1993. "The Moral Economy of the English Crowd in the Eighteenth Century." In Customs in Common: Studies in Traditional Popular Culture. New York: W. W. Norton \& Company, Inc.

Timpanaro, Sebastiano. 1976. The Freudian Slip: Psychoanalysis and Textual Criticism. trans. Kate Soper. London: New Left Books.

Wood, Ellen Meiksins. 1995. Democracy Against Capitalism. Cambridge: Cambridge University Press. 